\title{
Analysis of Unconfined Compressive Strength in Clay Mixed with Sand
}

\author{
Eko Budianto*, Dina Limbong Pamuttu, Simon Tatai, Daud Andang Passalli, and Hairulla Hairulla \\ Department Of Civil Engineering, Faculty of Engineering, UniversitasMusamus, Merauke, Indonesia
}

\begin{abstract}
Clay soils are soils that have high shrinkage potential and have good carrying capacity in water unsaturated conditions but poor in water-saturated conditions. Clay soil has a low carrying capacity, so to increase the carrying capacity of the soil it needs to be stabilized by using an added material which is sand. Land used for $100 \%$ disturbed soil, $95 \%$ disturbed soil $+5 \%$ sand, $90 \%$ disturbed soil $+10 \%$ sand, $85 \%$ disturbed soil $+15 \%$ sand, with curing time $3,7,14$, and 28 days. The mixture was tested using aunconfined compressive strength test instrument with SNI 03-6887-2002 method. The results of the unconfined compressive strength test showed that the increase in maximum soil strength occurred in the addition of $90 \%$ disturbed soil $+10 \%$ sand at the age of 28 days curing, which reached $1,194 \mathrm{~kg} / \mathrm{cm} 2$. But the results of unconfined compressive strength increased when the mixture of $85 \%$ disturbed soil $+15 \%$ of sand reaching $1,348 \mathrm{~kg} / \mathrm{cm} 2$. Based on testing that the more amount of sand is added, the higher the value of unconfined compressive strength obtained.
\end{abstract}

Keywords: Clay; Sand; Stabilization; Unconfined compressive strength; Analysis.

\section{Introduction}

Asmat Regency is located in Papua with an area of $31,983.69 \mathrm{~km}^{2}$ or $31.98 \%$ of the total area of Papua Province and is a division of Merauke Regency, the type of soil found in Asmat Regency consists of clay soil which is usually found in swampy areas and in lowland. In general, development in Asmat Regency is carried out on swamps and lowlands so that clay soil is a problem that must be overcome.

Clay soils have the property of expanding and developing several factors such as lithological variability at various scales, and cycles that vary repeatedly, on the behavior of clay [1] and have low bearing capacity. The compressive strength test of clay needs to be carried out to determine the compressive strength capacity of clay to be carried out with sand. Therefore, scientific and systematic research is needed to determine the character and proportion of each ingredient. In this study, the clay and sand materials used are local materials from several areas in Asmat Regency.

\section{Methods}

\subsection{Location of Sampling}

Obtaining the physical properties and mechanical properties of the soil that are limited in the UCS test was carried out at the Civil Engineering Laboratory, Musamus University, Merauke.

\subsection{Research Materials}

- Soil samples taken and used in this study were sourced from Akantapak Village, Aswi District, Asmat Regency.

- Sand samples taken and used in this study were sourced from Bawos Village, Aswi District, Asmat Regency.

\subsection{Method of testing}

- Testing of soil density is adjusted to SNI. [2] The tools used are hot plates, picnometers, ovens, electric scales, spatulas.

- Testing of water content is adjusted to SNI. [3] The tools used are ovens, cups, electric scales.

- Testing of grain analysis is adjusted to SNI. [4] The tools used are sieve filters, brushes, electric scales, water hoses, cups.

- Atterberg boundary testing devices are adjusted to SNI. [4, 5] est equipment used is casagrande, cup, glass with dimensions of $0.9 \mathrm{~cm} \times 45 \mathrm{~cm} \times 45 \mathrm{~cm}$, spatula, oven.

- Compaction test equipment adjusted to SNI. [6] The tools used are ovens, standard hammer proctors, standard proctors, electric scales, jacks.

\footnotetext{
* Corresponding author: budiyanto_ft@unmus.ac.id
} 
- Tests to get an overview of the results of this study using the unconfined compressive strength (UCS).

\section{Results and Discussions}

\subsection{Soil Properties}

Based on the results of testing the physical characteristics of the soil in the laboratory, the following data were obtained:

Table 1. Recapitulation of the results of testing the physical properties of the soil

\begin{tabular}{|c|c|c|c|c|}
\hline \multicolumn{5}{|c|}{$\pi$} \\
\hline No & Test type & Symbol & $\begin{array}{c}\text { Test } \\
\text { Result }\end{array}$ & Unit \\
\hline 1 & Water content & wc & 57.71 & $\%$ \\
\hline 2 & $\begin{array}{l}\begin{array}{l}\text { Specific } \\
\text { gravity }\end{array} \\
\end{array}$ & gs & 2.62 & \\
\hline 3 & Weight & $\gamma$ & 1.43 & grams $/ \mathrm{cm}^{3}$ \\
\hline 4 & \multicolumn{4}{|c|}{ Atterberg's boundaries } \\
\hline & a. Liquid Limit & LL & 71.15 & $\%$ \\
\hline & $\begin{array}{l}\text { b. Plastic } \\
\text { Limit }\end{array}$ & PL & 52.45 & $\%$ \\
\hline & c. IndexPlastic & PI & 18.40 & $\%$ \\
\hline 5 & \multicolumn{4}{|c|}{ Screening analysis } \\
\hline & a. Clay & & 30 & $\%$ \\
\hline & b. Silt & & 20 & $\%$ \\
\hline & c. Sand & & 30 & $\%$ \\
\hline & d. Gravel & & 0 & $\%$ \\
\hline
\end{tabular}

\subsection{Sand Properties}

Based on the results of testing the physical characteristics of sand carried out in the laboratory, the following data were obtained:

Table 2. Recapitulation of the results of testing the physical properties of sand

\begin{tabular}{|c|l|c|c|}
\hline No & \multicolumn{1}{|c|}{ Test } & Score & Unit \\
\hline 1 & $\begin{array}{l}\text { Moisture content of fine } \\
\text { aggregate (Sand) }\end{array}$ & 3.59 & $\%$ \\
\hline 2 & $\begin{array}{l}\text { Saturated surface dry density } \\
\text { (SSD) }\end{array}$ & 2.67 & $\%$ \\
\hline 3 & Oven dry weight (Bulk) & 2.61 & $\%$ \\
\hline 4 & Apparent dry density (Apprent) & 2.76 & $\%$ \\
\hline 5 & Absorption & 2.04 & $\%$ \\
\hline 6 & Pass filter 200 & 99.65 & $\%$ \\
\hline
\end{tabular}

\subsection{Unconfined Compressive Strength Test (UCS)}

In this study, the curing time used was 3 days, 7 days, 14 days and 28 days. In this test using a mixed variation of $100 \%$ disturbed soil, $95 \%$ disturbed soil $+5 \%$ sand, $90 \%$ disturbed soil $+10 \%$ sand, $85 \%$ disturbed soil $+15 \%$ sand . The results of the compressive strength test for undisturbed soil without a mixture of sand can be seen in table 3 .

Table 3. Testing of the compressive strength of undisturbed soil without a mixture of sand

\begin{tabular}{|c|c|c|c|c|}
\hline No. & Curring & $\begin{array}{c}\text { Value of } \\
\mathbf{q u} \\
(\mathbf{k g} / \mathbf{c m} 2)\end{array}$ & $\begin{array}{c}\text { Percentage } \\
\text { increase }\end{array}$ & $\begin{array}{c}\text { Stress } \\
\mathbf{( k g / m 2})\end{array}$ \\
\hline 1 & 3 & 0.894 & 0.12 & 0.447 \\
\hline 2 & 7 & 1.094 & 0.12 & 0.547 \\
\hline 3 & 14 & 1.433 & 0.12 & 0.716 \\
\hline 4 & 28 & 1,848 & 0.13 & 0.924 \\
\hline
\end{tabular}

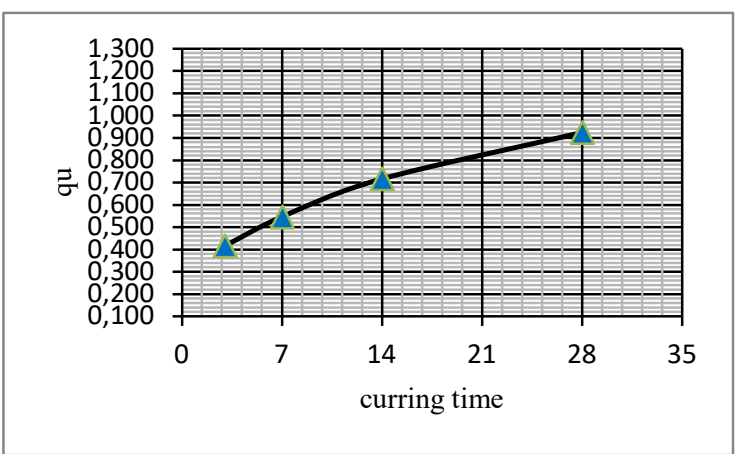

Fig.1. Graph of the relationship between ripening age and the value of $q u$ in the $100 \%$ soil test

Based on the results of the test data obtained and the graphic image shows the compressive strength of the disturbed soil without a mixture of sand at the age of 3 days is $0.416 \mathrm{~kg} / \mathrm{cm}^{2}$, while at the age of 28 days there is an increase of $0.924 \mathrm{~kg} / \mathrm{cm}^{2}$. The results of the undisturbed compressive strength test with a mixture of $95 \%$ soil and $5 \%$ sand can be seen in Table 4 .

Table 4. Test of soil unconfined compressive strength with a mixture of $95 \%$ soil and $5 \%$ sand

\begin{tabular}{|c|c|c|c|c|}
\hline No. & Curring & $\begin{array}{c}\text { Value of qu } \\
\text { (kg/cm2) }\end{array}$ & $\begin{array}{c}\text { Percenta } \\
\text { ge } \\
\text { increase }\end{array}$ & $\begin{array}{c}\text { Stress } \\
(\mathbf{k g} / \mathbf{m} 2)\end{array}$ \\
\hline 1 & 3 & 1.063 & 0.12 & 0.531 \\
\hline 2 & 7 & 1.309 & 0.13 & 0.655 \\
\hline 3 & 14 & 1,725 & 0.13 & 0.863 \\
\hline 4 & 28 & 2,311 & 0.13 & 1.078 \\
\hline
\end{tabular}

Based on the results of the test data obtained and the graphic image shows the value of the compressive strength of undisturbed soil with a mixture of $95 \%$ soil and $5 \%$ sand at the age of 3 days is $0.531 \mathrm{~kg} / \mathrm{cm}^{2}$, while at the age of 28 days there is an increase of $1,078 \mathrm{~kg} / \mathrm{cm}^{2}$. The results of the undisturbed compressive strength test with a mixture of $90 \%$ soil and $10 \%$ sand can be seen in table 5 . 


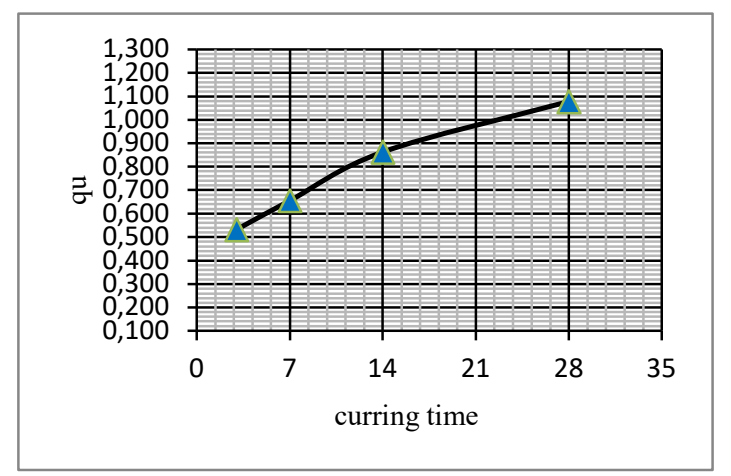

Fig.2. Graph of the relationship between curing and the value of qu in the $95 \%$ soil $+5 \%$ sand test

Table 5. Value of undisturbed compressive strength of soil with a mixture of $90 \%$ soil and $10 \%$ sand

\begin{tabular}{|c|c|c|c|c|}
\hline No. & $\begin{array}{c}\text { Currin } \\
\mathbf{g}\end{array}$ & $\begin{array}{c}\text { Value of } \\
\mathbf{q u} \\
\mathbf{( k g / c m} 2)\end{array}$ & $\begin{array}{c}\text { Percentage } \\
\text { increase }\end{array}$ & $\begin{array}{c}\text { Stress } \\
\mathbf{( k g} / \mathbf{m} 2)\end{array}$ \\
\hline 1 & 3 & 1.217 & 0.13 & 0.608 \\
\hline 2 & 7 & 1.556 & 0.12 & 0.778 \\
\hline 3 & 14 & 1969 & 0.12 & 0.985 \\
\hline 4 & 28 & 2,388 & 0.12 & 1.194 \\
\hline
\end{tabular}

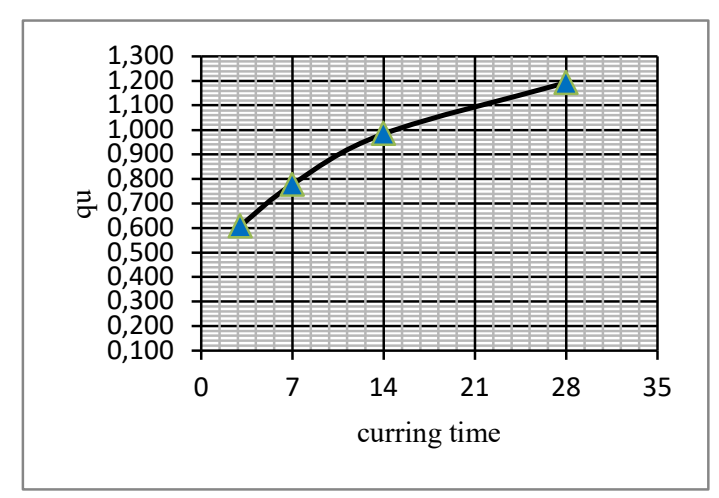

Fig.3. Graph of the relationship between curing and the value of $q u$ in the test of $90 \%$ soil and $10 \%$ sand

Based on the results of the test data obtained and the graphic image shows the compressive strength of disturbed soil with a mixture of $90 \%$ soil and $10 \%$ sand at the age of 3 days is $0.608 \mathrm{~kg} / \mathrm{cm}^{2}$, while at the age of 28 days there is an increase of $1.194 \mathrm{~kg} / \mathrm{cm}^{2}$. The results of the undisturbed compressive strength test with a mixture of $85 \%$ soil and $15 \%$ sand can be seen in Table 6 .

Table 6. Value of undisturbed compressive strength of soil with a mixture of $85 \%$ soil and $15 \%$ sand

\begin{tabular}{|c|c|c|c|c|}
\hline No. & Curring & $\begin{array}{c}\text { Value of } \\
\mathbf{q u} \\
(\mathbf{k g} / \mathbf{c m} 2)\end{array}$ & $\begin{array}{c}\text { Percentage } \\
\text { increase }\end{array}$ & $\begin{array}{c}\text { Stress } \\
\mathbf{( k g / m 2})\end{array}$ \\
\hline 1 & 3 & 1.417 & 0.12 & 0.709 \\
\hline 2 & 7 & 1,742 & 0.12 & 0.871 \\
\hline 3 & 14 & 2.138 & 0.12 & 1.069 \\
\hline 4 & 28 & 2,696 & 0.12 & 1.348 \\
\hline
\end{tabular}

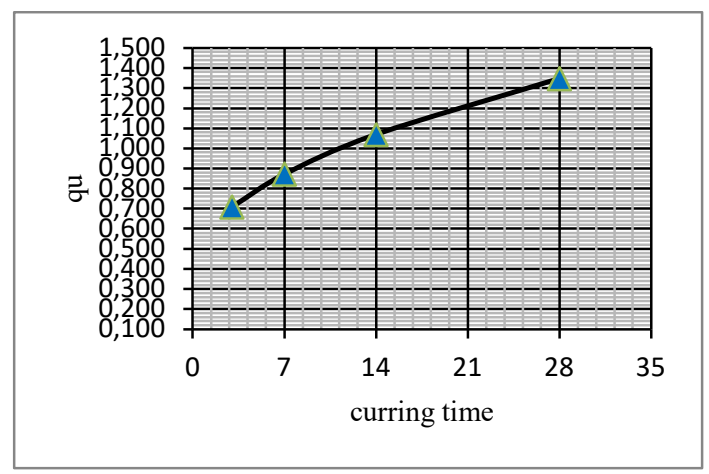

Fig.4. Graph of the relationship between curing and the value of qu in the test of $85 \%$ soil and $15 \%$ sand

Based on the results of the test data obtained and the graphic image shows the compressive strength of disturbed soil with a mixture of $85 \%$ soil and $15 \%$ sand at the age of 3 days is $0.709 \mathrm{~kg} / \mathrm{cm}^{2}$, while at the age of 28 days there is an increase of $1.348 \mathrm{~kg} / \mathrm{cm}^{2}$.

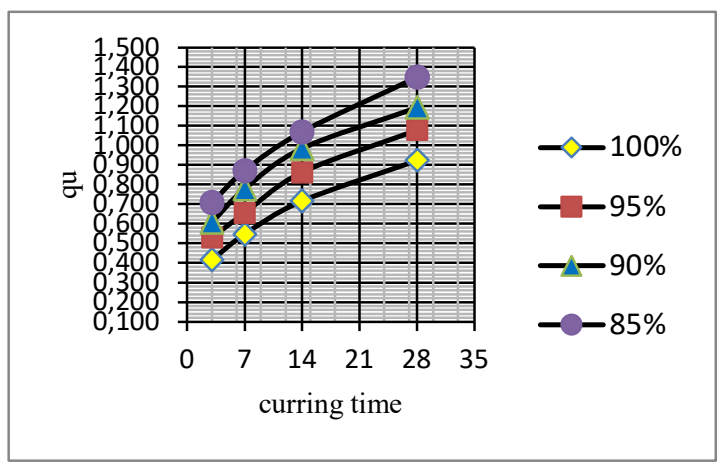

Fig.5. Graph of the effect of curing on the value of stress (qu) with mixed variations variasi

Based on the results of calculations on the UCS test for a mixture of soil and sandit can be concluded that the more addition of sand and the longer the curing age the higher the value of qu is shown in Figure 5.

Table 7. The results of the recap of the average independent compressive strength value

\begin{tabular}{|c|c|c|}
\hline Variations & Curring Time & $\begin{array}{c}q u \\
\left(\mathrm{~kg} / \mathrm{cm}^{2}\right)\end{array}$ \\
\hline \multirow{4}{*}{$100 \%$ Land Disturbed } & 3 & 0.447 \\
\hline & 7 & 0.547 \\
\hline & 14 & 0.716 \\
\hline & 28 & 0.924 \\
\hline \multirow{4}{*}{$\begin{array}{c}95 \% \text { Land Disturbed }+ \\
5 \% \text { Sand }\end{array}$} & 3 & 0.531 \\
\hline & 7 & 0.655 \\
\hline & 14 & 0.863 \\
\hline & 28 & 1.078 \\
\hline \multirow{4}{*}{$\begin{array}{c}90 \% \text { Land Disturbed }+ \\
10 \% \text { Sand }\end{array}$} & 3 & 0.608 \\
\hline & 7 & 0.778 \\
\hline & 14 & 0.985 \\
\hline & 28 & 1.194 \\
\hline \multirow{4}{*}{$\begin{array}{c}85 \% \text { Land Disturbed + } \\
15 \% \text { Sand }\end{array}$} & 3 & 0.709 \\
\hline & 7 & 0.871 \\
\hline & 14 & 1.069 \\
\hline & 28 & 1.348 \\
\hline
\end{tabular}




\section{Conclusion}

Based on the results of the research and discussion above, it can be concluded that the maximum unconfined compressive strength test results occurred at 28 days of curing as follows:

a. Score The unconfined compressive strength of the clay subgrade in Akantapak village is $0.924 \mathrm{~kg} / \mathrm{cm}^{2}$.

b. Influence clay soil with mixer local sand against unconfined compressive strength.

- $95 \%$ land disturbed $+5 \%$ sand obtained the value of qu $=1.078 \mathrm{~kg} / \mathrm{cm}^{2}$.

- $90 \%$ land disturbed $+10 \%$ sand obtained the value of qu $=1.194 \mathrm{~kg} / \mathrm{cm}^{2}$.

- $85 \%$ Disturbed soil $+15 \%$ sand obtained the value of qu $=1.348 \mathrm{~kg} / \mathrm{cm}^{2}$.

Judging from the test results above, it can be seen that the optimum qu occurs in the variation of the mixture of $90 \%$ disturbed soil $+10 \%$ sand of $1,194 \mathrm{~kg} / \mathrm{cm}^{2}$, and the effect of the addition of a mixture of sand can increase the strength of the soil, it can be seen in the test results above, where at the time of testing the sample of $85 \%$ disturbed soil $+15 \%$ sand obtained a qu value of $1.348 \mathrm{~kg} / \mathrm{cm}$.

\section{References}

1. Andrieux, C. Shrinkage and swelling of clay soil. European Journal of Environmental and Civil Engineering. 15:5, 819-838. (2011)

2. Anonymous. Soil Plastic Limit Test Method, (SNI 03-1966-1990). National Standards Agency, Jakarta. (1998).

3. Anonymous. Aggregate Moisture Testing Method, (SNI 03 - 1971 - 1990). National Standards Agency, Jakarta. (1990).

4. Anonymous, How To Test Soil Grain Size Analysis. (SNI 3423:2008). National Standards Agency, Jakarta. (2008).

5. Sazuatmo. Effect of Plastic Material on Shear Strength in Clay Soil. Journal of Civil Engineering UBI, Vol. 2 No. 1:110\&115. (2011).

6. Anonymous, Method of Testing Heavy Density For Soil. (SNI 1743:2008). National Standards Agency, Jakarta. (2008) 